\title{
ANALISIS TINGKAT ERGONOMI POSTUR KERJA KARYAWAN DI LABORATORIUM KCP PT. STEELINDO WAHANA PERKASA DENGAN METODE RAPID UPPER LIMB ASSESSMENT (RULA), RAPID ENTIRE BODY ASSESSMENT (REBA) DAN OVAKO WORKING POSTURE ANALISYS (OWAS)
}

\author{
Mochamad Imron, S.Si.,MT. \\ Dosen Teknik Industri Universitas Pamulang \\ dosen 854@unpam.ac.id
}

\begin{abstract}
ABSTRAK
Penelitian ini akan menganalisis keletihan tubuh petugas laboratorium yang akan di ukur dengan metode RULA dan REBA untuk menginvestigasi gangguan pada anggota tubuh pekerja. Untuk itu mendorong peneliti untuk melakukan penelitian sistem kerja tersebut yang diberi judul " Analisis tingkat ergonomi postur kerja karyawan di laboratorium kcp PT. Steelindo Wahana Perkasa dengan metode Rapid Upper Limb Assessment (RULA), Rapid Entire Body Assessment (REBA) dan Ovako Working Posture Analisys (OWAS)". Adapun tujuan penelitian ini untuk menganalisis postur kerja pada petugas laboratorium kcp PT.Steelindo Wahana Perkasa saat ini dan mengevaluasi postur kerja yang mempengaruhi pencapaian produktifitas dengan Metode RULA, REBA, dan OWAS di laboratorium kcp PT.Steelindo Wahana Perkasa. Kesimpulan dari penelitian ini adalah 1. Postur kerja para karyawan pada saat bekerja di PT. Steelindo Wahana Perkasa dalam kegiatan pemisahan cangkang kernel adalah Postur kerja duduk pada elemen kegiatan ini, agak merunduk serta dengan posisi kedua tangan sedikit di atas meja, dengan posisi kedua kaki lulus ke bawah meja 2. Berdasarkan analisa dari 3 metode yang digunakan yaitu metode RULA, REBA, dan OWAS maka didapatkan kesimpulan bahwa Berdasarkan hasil analisa menggunakan metode RULA posutr kerja pada karyawan laboratorium kcp PT.Steelindo Wahana Perkasa mendapatkan skor 6 yaitu kategori resiko sedang, sedangkan berdasarkan menggunakan metode REBA maka didapatkan hasil skor 7 yaitu kategori action 2 yaitu berisiko sedang, sedangkan analisis metode OWAS di dapatkan hasil skor 1 dengan kategori tidak terlalu berisiko/ berisiko sedang.
\end{abstract}

Kata kunci: Ergonomi, RULA, REBA, OWAS

\section{PENDAHULUAN}

Penerapan ergonomi sangat perlu diperhatikan karena kurangnya perhatian terhadap penerapan ergonomi ditempat kerja bisa menyebabkan resiko bahaya yang ada dapat dikurangi. Postur kerja merupakan titik penentu dalam menganalisis keefektifan dari suatu pekerjaan. Jika postur kerja yang dilakukan oleh operator sudah baik dan ergonomis maka dapat dipastikan hasil yang diperoleh oleh operator tersebut akan baik. Akan tetapi bila postur kerja operator tersebut salah atau tidak ergonomis maka operator tersebut mudah kelelahan dan terjadi kelainan pada bentuk tulang. Apabila operator mudah mengalami kelelahan hasil pekerjaan yang dilakukan operator tersebut juga mengalami penurunan dan tidak sesuai dengan yang diharapkan seperti yang dilajaskan oleh Bayu krisna sandi ( 2 18).

Pada PT.Steelindo Wahana Perkasa unit kcp terdapat departemen analisis yang diperuntukan menganalisis sample karnel, sample pko dan sample pke. Karyawan laboratoriun unit kcp PT. Steelindo Wahana Perkasa bekerja dengan posisi berdiri, dan duduk, jenis pekerjaan ini apabila dibiarkan akan menimbulkan kelelahan ditambah lagi postur tubuh karyawan yang berbeda-beda, sehingga konsentrasi karyawan akan menurun dan kinerja juga memungkin untuk ikut menurun. Karena itulah peneliti tertarik untuk menganalisis postus kerja pada petugas laboratorium unit kcp PT. Steelindo Wahana Perkasa. 


\section{DASAR TEORI}

Ergonomi dapat di definisikan sebagai suatu disiplin yang mengkaji keterbatasan, kelebihan serta karakteristik manusia, dan memanfatkan informasi tersebut dalam merancang produk, mesin, fasilitas, lingkungan dan bahkan sistem kerja, dengan tujuan uatam tercapinya kualitas kerja yang terbaik tanpa mengabadikan aspek kesehatan, keselamatan dan kenyamanan manusia atau penggunanya . mengacu pada definisi ini, dapat dikatan bahkan hampir semua rancangan objek yang berhubungan ( berinteraksi ) dengan manusia memerlukan ilmu ergonomic. Beberpa definisi serta pengertian mengenai ergonomi dapat dilihat pada poin-poin berikut :

1. Ergonomi merupakan suatu ilmu antar disiplin , yang mengkaji interaksi antara manusia dan ojek yang mereka gunakan.

2. Chengalur Et Al dalam Iridiastadi dan Yassierli (2 17) ergonomi adalah suatu aktivitas multi disiplin yang diarahkan untuk mengumpulkan informasi tentang kapasitas dan kemampuan manusia, dan memanfaatkannya dalam merancang pekerjaan, produk, tempat kerja dan peralatan kerja.

3. Kuswan (2 17) istilah ergonomi dikenal dalam bahasa Yunani yaitu ergos dan nomos yang memiliki arti " kerja" dan " aturan dan kaidah", dari dua kata tersebut secara pengertian bebas sesuai dengan perkemangannya, yakni satu aturan atau kaida yang ditaati dalam lingkungan pekerjaan.

Ergonomi dapat mengurangi beban kerja. Dengan evaluasi fisiologis, psikologis atau caracara tidak langsung, beban kerja dapat diukur dan dianjurkan modifikasi yang sesuai diantara kapasitas kerja dan beban kerja serta beban tambahan. Tujuan utamanya adalah untuk menjamin kesehatan kerja, sehingga produktivitas juga dapat ditingkatkan. Dalam evaluasi kapasitas dan isi kerja, perhatian utama perlu diberikan kepada kegiatan fisik, yaitu postur kerja, intensitas, tempo, jam kerja, waktu istirahat dan pengaruh keadaan lingkungan.

\section{METODOLOGI PENELITIAN}

\section{A.Teknik Pengumpulan Data}

Metode pengumpulan data dengan mengadakan pengamatan langsung pada obyek yang diteliti. Observasi dilakukan guna mendapatkan data postur tubuh tenaga kerja dengan merekam ataupun pengambilan foto dari pekerja. Pengumpulan data dengan cara melakukan tanya jawab dengan nara sumber yang terkait dengan penelitian yang dilakukan, wawancara dilakukan pada sejumlah karyawan di bagian produksi. Maka dalam penelitian ini digunakan metode pengumpulan data sebagai berikut:

1. Landasan Teori

Yaitu bentuk penelitian yang dilakukan dengan membaca literatur-literatur, karangan ilmiah serta berbagai bahan pustaka lainnya yang ada hubungannya dengan penulisan tugas akhir ini yang membahas ergonomi dalam postur kerja karyawan , guna memperoleh landasan teori yang memadai untuk melakukan pembahasan.

2. Penelitian Lapangan

Penelitian yang dilakukan secara langsung pada lokasi penelitian dengan menggunakan teknik wawancara (Interview) dengan pihak yang berkompeten (karyawan) terhadap data yang di perlukan oleh penulis serta pengumpulan data dokumen-dokumen atau data-data yang di anggap relevan dengan masalah yang di teliti. Selain itu penulis juga wawancara kepada pihak pihak yang berkompeten untuk melengkapi keakuratan data untuk tugas akhir ini.

3. Dokumentasi

Dokumentasi merupakan catatan peristiwa yang sudah berlalu. Dalam penelitian ini metode dokumentasi digunakan untuk mengumpulkan data tentang sikap kerja karyawan yang ada kaitannya dengan penentuan analisa postur kerja karyawan laboratorium kcp PT. Steelindo Wahana Perkasa.

\section{B.Flowchart Penelitian}

Berikut adalah alur pelaksanaan penelitian yang dilakukan oleh penulis di laboratoium kcp PT.Steelindo Wahana Perkasa tercantum dalam Gambar 3.1 


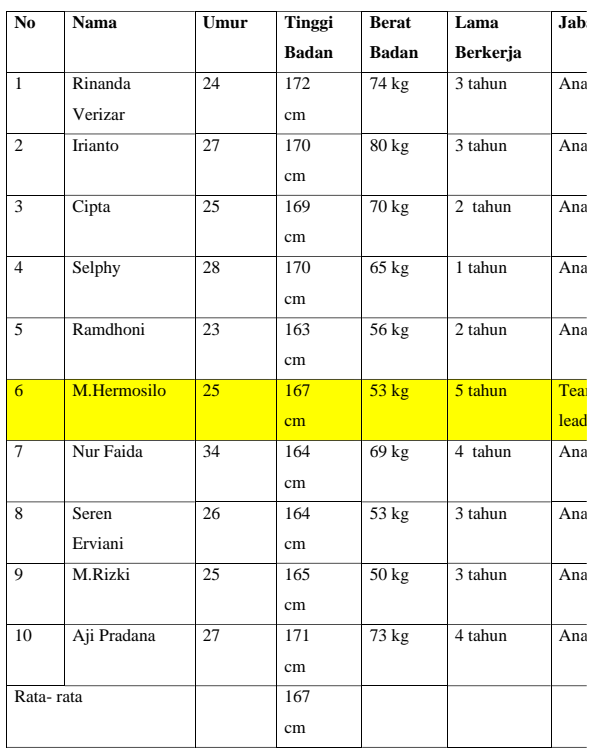

( Sumber : Hasil Penelitian Pribadi)

Maka diambillah 1 karyawan sesuai dengan rata-rata tinggi badan yaitu M.hermosilo dengan tinggi badan $167 \mathrm{~cm}$. Postur kerja yang akan diteliti adalah postur kerja untuk melaksanakan kegiatan analisis pada laboratorium $\mathrm{kcp}$. Postur kerja yang dimaksud adalah Postur kerja duduk pada elemen kegiatan melakukan pemisahan cangkang kernel untuk di analisis kandungan cangkang dan pko yang terkandung pada biji kerjnel tersebut .

\section{B. Analisis Postur Kerja Menggunakan Metode RULA}

Sebelum kandungan sisa cangkang kernel di analisis maka dilakukan kegiatan pemisahan cangkang dari biji kernel dan untuk postur kerja pada karyawan 1 terlihat pada

\section{Pembuatan Pribadi)}

Sumber: Hasil

Gambar 3.1 Flowchart Penelitian

\section{HASIL DAN PEMBAHASAN}

\section{A. Data Penelitian}

Dari 1 orang karyawan diambil 1 orang, untuk sampel penelitian. Berdasarkan rata-rata tinggi karyawan didapat satu orang karyawan sebagai sampel penelitian dengan tinggi sebagai berikut :

Tabel 4.1 Data Karyawan Laboratorium Kcp PT.Steelindo Wahana Perkasa

\section{Gambar 4.1}
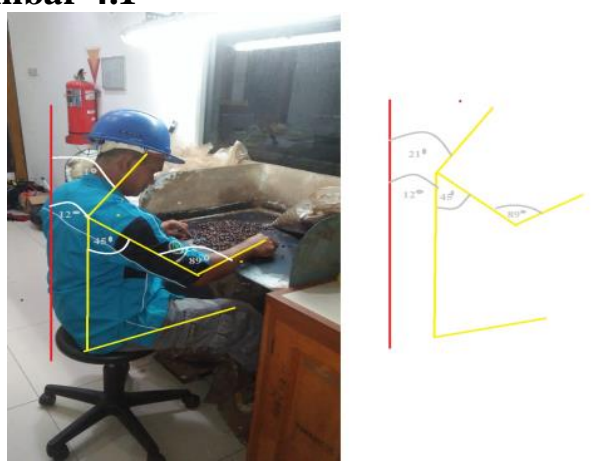

Gambar 4.1 Postur Duduk Pada Karyawan Untuk Penilaian Metode RULA

Dari Gambar 4.1 dapat terlihat bahwa postur kerja yang dilakukan yaitu postur duduk 
dengan posisi tangan kiri dan tangan kanan ditekuk kedepan, berdasarkan pengukuran yang di apatkan maka diperoleh hasil sebagai berikut:

1. Postur tubuh grup A

Skor postur kerja grup A

$\begin{array}{llll}\text { a. Lengan } & \text { atas } & \text { (upper } & \text { arm) } \\ & =1 & & \\ \text { b. Lengan } & \text { bawah } & \text { (lower } & \text { arm) } \\ & =2 & & \\ \text { c. } \text { Pergelangan } & \text { tangan } & \text { (wrist) } \\ = & & & \end{array}$

d. Putaran pergelangan tangan (wrist twist)

$=2$

Nilai dari postur tubuh lengan atas (upper arm), lengan bawah (lower arm), pergelangan tangan (wrist) dan putaran pergelangan tangan (wrist twist) kemudian dimasukkan kedalam tabel postur tubuh grup.

\section{Postur Kerja Karyawan Laboratorium}

Berdasarkan dari hasil pengolahan data dan analisa menggunakan metode RULA yang dilakukan terhadap elemen kegiatan pada kegiatan pemisajahan cangkang Postur Kerja Duduk Pada Proses Pengaturan Awal Mesin Sebelum Dioperasikan Mendapat Skor 6 Yang Termasukdalam Level Resiko sedang. Hasil analisis menggunakan metode REBA dari hasil pengolahan data dan analisa yang di lakukan pada elemen kegiatan pemisahan cangkang kernel pada grub a yang mengcangkup punggung, leher dan kaki yang masing- masing mendapatkan skor : punggung 2, leher 2, kaki 3. Sedangkan untuk grub A yang terdiri dari lengan atas, lengan bawah, pergelangan tangan yang masing-masing mendapatkan skor: lengan bawah 2, lengan atas 3, pergelangan $2 \mathrm{kali} / \mathrm{menit})$. Berdasarkan literatur, kegiatan tersebut memperoleh skor aktivitas. Skor REBA $=$ Skor $C+$ skor aktivitas $=6+1=7$. Skor 7 pada Skor $\mathrm{C}$ menunjukkan bahwa perlu adanya tindakan dari PT. Steelindo Wahana Perkasa secepatnya untuk menghindari adanya keluhan musculoskeletal yang mungkin akan terjadi. Hal ini dikarenakan skor 7 termasuk dalam skala level dengan resiko sedang bagi postur kerja pada petugas laboratorium kcp PT. Steelindo Wahana Perkasa .
Dari hasil analisa metode OWAS adalah tentang klasifikasi tingkat resiko pada kombinasi posisi didapatkan hasil yang termasuk pada kategori 1 yaitu : Pada sikap ini tidak ada masalah pada sistem musculoskeletal dan Tidak perlu ada perbaikan.

\section{Usulan Kursi}

Berikut adalah ususlan perbaikan kursi yang bisa digunakan karyawan laboratorium $\mathrm{kcp}$ saat melakukan pekerjaan pemisahan cangkang kernel. Seperti terlihat pada Gambar 4.9

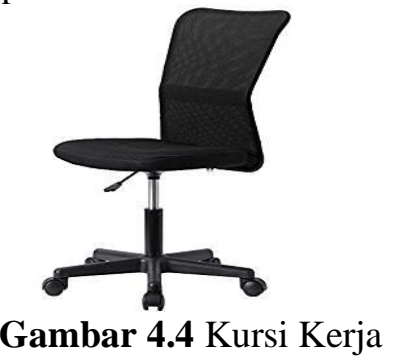

\section{Kesimpulan}

Hasil dari analisa yang diperoleh di dapat kesimpulan sebagai berikut:

1. Postur kerja para karyawan pada saat bekerja di PT. Steelindo Wahana Perkasa dalam kegiatan pemisahan cangkang kernel adalah Postur kerja duduk pada elemen kegiatan ini, agak merunduk serta dengan posisi kedua tangan sedikit di atas meja, dengan posisi kedua kaki lulus ke bawah meja.

2. Berdasarkan analisa dari 3 metode yang digunakan yaitu metode RULA, REBA, dan OWAS maka didapatkan kesimpulan bahwa Berdasarkan hasil analisa menggunakan metode RULA posutr kerja pada karyawan laboratorium $\mathrm{kcp}$ PT.Steelindo Wahana Perkasa mendapatkan skor 6 yaitu kategori resiko sedang, sedangkan berdasarkan menggunakan metode REBA maka didapatkan hasil skor 7 yaitu kategori action 2 yaitu berisiko sedang, sedangkan analisis metode OWAS di dapatkan hasil skor 1 dengan kategori tidak terlalu berisiko/ berisiko sedang. Dari ketiga hasil analisis ini penulis mengambil kesimpulan bahwa perlu adanya Evaluasi Di Karenakan meja dan kursi kerja ini sebelumnya tidak dilakukan pertimbangan terhadap konsep ergonomi, pekerja harus menyesuaikan duduk dengan 
meja untuk pada saat memilih kernel, posisi badan pekerja harus lebih tegap agar posisi melihat mesin dan objek kerja lebih rileks. Alternatif perbaikan alat kerja untuk permasalahan ini adalah dengan merancang kembali kursi kerja dengan ukuran kursi yang menyesuaikan rata-rata tinggi pekerja, sehingga postur kerja yang tidak nyaman dapat dikurangi.

\section{DAFTAR PUSTAKA}

Anggaa Aprillian, 218 Analisis Postur Tubuh Atlet Karate Kata Pada Saat Nelakukan Gerakan Tangkisan Dengan Menggunakan Metode RULA Dan REBA Serta Asupan Gizi Standar Di Federasi Olahraga Karate Indonesia (Forki). Kota Tanggerang,

Bayu Krisna Sandi, 218 Analisis Postur Kerja Karyawan Dengan Menggunakan Metode Rapid Upper Limb Assissment (RULA) Di Ukm Raga Alam Sewing Serang. Tanggerang Selatan

Bridger,R.S 2 15. Introduction To Ergonomics, McGRAW-HILL

C.Pearce, Evelyn.2 12. Anatomi Dan Fisiologi. Jakarta: PT. Gramedia Pustaka Guna Utama

Dinda Safitri Ramadhani, 217 Analisis Postur Kerja Dengan Posture Evaluation Index Untuk Perancangan Stasiun Kerja Pada Divisi Finishing Dalam Virtual Environment. Surakarta

Dircia Fernandes Correia, Muhhammad Yusuf, Risma Adelina Simanjuntak, 216 Analisis Postur Kerja Menggunakan Metode Rapid Upper Limb Assessment (RULA) Dan Working Postur Analysis Sistem (OWAS). Jakarta Barat

International Labour Organization, 213. Keselamatan Dan Kesehatan Kerja Untuk Protuktivitas Kerja. Jakarta
Organization

Nurul Dzikrillah. 215 Analisis Postur Kerja Menggunakan Metode Rapid Upper Limb Assessment (RULA) Studi Kasus PT. TJ Forge Indonesia, JAKARTA

Rafiudrojat.2 18, Analisis Postur Tubuh Pekerja Pada Bagaian Muat Barang ( Loding) Dengan Metode Rula Dan Reba Untuk Mengurangi Resiko Terjadinya Musculoskeletal Di PT. Indomarco Prismatama, Tanggerang Selatan.

Prastiwa Ageng Pratama. 2 12, Analisis Posisi Kerja Bagian Pengelasan Dibengkel Perbaikan Bodi Kendaraan Roda Empat Dengan Mengguankan Virtual Enciroment Modeling, Depok.

Tarwaka, Solichul, Sudiajeng, L. 214 . Ergonomi Untuk Keselamatan, Kesehatan Dan Produktivitas, Uniba Press, Surakarta.

Utaminingsih, S., \& Candra, A. (2015). Penentuan Lama Waktu Istirahat Berdasarkan Beban Kerja Dengan Menggunakan Pendekatan Fisiologis Disaint JOHN'S SCHOOL BSD. Teknologi, Jurnal Ilmiah dan teknologi, Fakultas Teknik Dan Fakultas MIPA Universitas Pamulang, 11(29), 112.

Yustina Widyarti, 216 Analisis Risiko Postur Kerja Dengan Metode Quick exposure Checklist (QEC) Dan Pendekatan Fisiologi Pada Proses Pembuatan Tahu. Surakarta

https://www.ilo.org/jakarta/info/public/pr/WCM S_616368/lang--en/index.htm https://www.pelajaran.co.id/2 17/3 /pengertianergonomi-ruang-lingkup-tujuan-fungsi-manfaatdan-prinsip-ergonomi.html https://iniputri.blog.uns.ac.id/files/2 1 / 5/pti2 modul2 42 evaluasi 2 ergonomi.pdf 